main plutonic centres were emplaced. The effect of intrusions of the central gabbros (interpreted as floored layered complexes) would have caused only further uplift of the roofing country rocks. It is thus not surprising that the Ben Hiant vent, which lies just on the edge of all this uplift, is relatively low and early.

Looking forward, the question now arises: what proportions of the elevation of such a volcano as Mauna Loa or Etna might be due to a similar mechanism of uplift? The answer would help to solve some of the problems of lunar and martian volcanic structures.

\title{
References
}

Green, J. \& Wright, J. B. 1974. Ardnamurchan, Centre 1 - new radiometric evidence. Geol. Mag. 111, 163-4.

Le Bas, M. J. 1971. Cone-sheets as a mechanism of uplift. Geol. Mag. 108, 373-6.

Richey, J. E. \& Thomas, H. H. 1930. The geology of Ardnamurchan, north-west Mull, and Coll. Mem. geol. Surv. Scotland.

\section{The petrology of the Warsak alkaline granites, Pakistan, and their relationship to other alkaline rocks of the region: Corrigendum}

SIR, - It is regretted that some of the trace-element data in Kempe (1973) are in error. The following corrected data should be substituted in Table 3, p. 394:

\begin{tabular}{lrrrrrrrr}
\hline & 3 & 4 & 5 & 6 & 7 & 8 & 9 & 10 \\
\hline Sr & $<20$ & n.d. & 72 & n.d. & 317 & n.d. & - & n.d. \\
Ba & 645 & 550 & 425 & 555 & 1595 & 405 & - & 245 \\
$\mathrm{Rb}$ & 144 & 118 & 56 & 110 & 105 & 180 & - & 205 \\
& \multicolumn{7}{c}{ n.d.: not detected } \\
\hline
\end{tabular}

\section{Reference}

Kempe, D. R. C. 1973. The petrology of the Warsak alkaline rocks, Pakistan, and their relationship to other alkaline rocks of the region. Geol. Mag. 110, 385-404.

Department of Mineralogy

D. R. C. KEMPE

British Museum (Natural History)

London SW7 5BD

1st May 1974 